\title{
PENURUNAN TOTAL TANIN SILASE SEMAK BUNGA PUTIH (Chromolaena odorata) DENGAN ADITIF TEPUNG PUTAK (Coryphaelata robx) DAN ISI RUMEN SAPI
}

\section{DECREASING OF TOTAL TANNINS FROM Chromolaena odorata SILAGE WITH THE ADDITIVES OF PUTAK MEAL AND RUMEN CONTENT}

\author{
Muhammad Ridla ${ }^{1 *}$, Yelly Magdalena Mulik ${ }^{2}$, Iwan Prihantoro ${ }^{1}$, dan Marthen Luther \\ Mullik ${ }^{2}$ \\ ${ }^{1}$ Departemen Ilmu Nutrisi dan Teknologi Pakan, Fakultas Peternakan, Institut Pertanian Bogor, Bogor, \\ 16680 \\ ${ }^{2}$ Program Studi IImu Peternakan, Fakultas Peternakan, Universitas Nusa Cendana, Kupang, 85001
}

Submitted: 2 September 2016, Accepted: 4 October 2016

\section{INTISARI}

Penelitian ini bertujuan untuk mengkaji pengaruh penambahan zat aditif berupa tepung putak (sebagai sumber karbohidrat) dan isi rumen (sebagai sumber enzim) dalam pembuatan silase C. odorata terhadap kandungan total tanin dan kandungan nutrien silase $C$. odorata. Perlakuan yang digunakan terdiri atas 4 macam, yaitu: CO (C. odorata), COP (C. odorata + tepung putak 10\%), COPR5 (C. odorata + tepung putak $10 \%$ + isi rumen $5 \%$ ), dan COPR10 (C. odorata + tepung putak 10\% + isi rumen 10\%). Rancangan percobaan yang digunakan adalah Rancangan Acak Lengkap pola faktorial $4 \times 2$. Faktor pertama adalah perlakuan (CO, COP, COPR4, COPR10) dan faktor kedua adalah waktu fermentasi silase (0 hari dan 21 hari). Masing-masing perlakuan diulang sebanyak 4 kali. Peubah yang diukur adalah kandungan konsentrasi total tanin dan kandungan nutrien. Hasil penelitian menunjukkan penurunan total tanin $15,50 \%$ pada silase dengan penambahan aditif (tepung putak $10 \%$ dan isi rumen $10 \%$ ). Kandungan nutrien (BO dan PK) meningkat masing-masing 3,45\% dan 41,81\% serta terjadi penurunan serat kasar $3 \%$ bila dibandingkan silase tanpa aditif. Waktu fermentasi silase C.odorata selama 21 hari menghasilkan kualitas silase terbaik dibanding waktu fermentasi 0 hari.

(Kata kunci: Chromolaena odorata, Isi rumen, Nutrien, Silase, Tanin, Tepung putak)

\section{ABSTRACT}

This study was aimed to assess the effect of the addition of putak meal (as a source of carbohydrates) and rumen content (as a source of enzymes) in the making of $C$. odorata silage to the total content of tannins and nutrient content of $C$. odorata silage. The treatments were: $C O$ (C. odorata), COP (C. odorata $+10 \%$ of putak meal), COPR5 (C. odorata $+10 \%$ of putak meal $+5 \%$ of rumen content), and COPR10 (C. odorata $+10 \%$ of putak meal $+10 \%$ of rumen content). The experimental design used was Completely Randomized Design, with $4 \times 2$ factorial patterns. The first factor was the treatment (CO, COP, COPR4, COPR10) and the second factor is the silage fermentation time (0 days and 21 days). Each treatment was replicated 4 times. The variables measured were concentration of total tannin content and nutrient content. The results showed that the addition of (10\% of putak meal and $10 \%$ of rumen content) decrease total tannins of the silage by $15.50 \%$. The nutrient content (OM and OP) increased by $3.45 \%$ and $41.81 \%$ respectively as well as a decline in crude fiber $3 \%$ when compared to the silage without additives. Fermentation time of $C$. odorata silage for 21 days produced the best quality silage fermentation time compared to 0 days.

(Key words: Chromolaena odorata, Nutrient, Putak meal, Rumen content, Silage, Tannins)

\section{Pendahuluan}

Chromolaena odorata merupakan jenis semak perdu berkayu tahunan yang dianggap sebagai salah satu jenis gulma yang paling invasif di dunia karena mendominasi padang penggembalaan, bersifat alelopati serta

\footnotetext{
* Korespondensi (corresponding author):

Telp. +62 85213794121, E-mail: hmridla@yahoo.com
}

bersifat allergen/toxic bagi manusia dan ternak (Hawaii Department of Agriculture, 2016). C. odorata memiliki kandungan senyawa metabolit sekunder antara lain tanin, alkaloid, phlobatanin, steroid, terpenoid, dan flavonoid (Akinmoladun et al., 2010). Kandungan protein kasar C. odorata $17,54 \%$ sehingga dapat dimanfaatkan sebagai pakan, 
namun terkendala oleh keberadaan senyawa metabolit yang menyebabkan palatabilitas $C$. odorata rendah (Hai et al., 2012).

Pengolahan silase merupakan metode terbaik untuk menurunkan kandungan total tanin C. odorata. Mulik et al. (2016) melaporkan bahwa metode pengolahan silase tanpa aditif mampu menurunkan $62 \%$ kandungan total tanin $C$. odorata. Penambahan aditif baik sumber karbohidrat maupun enzim sangat diperlukan untuk meningkatkan kualitas silase. Hal ini dikarenakan C. odorata memiliki kandungan protein yang sangat tinggi $(17,54 \%)$, cenderung meningkatkan $\mathrm{pH}$ sehingga aktivitas bakteri asam laktat terhambat.

Putak merupakan salah satu bahan sumber karbohidrat lokal yang sudah umum dikenal masyarakat di Pulau Timor, Nusa Tenggara Timur. Putak diperoleh dari bagian tengah (isi) batang pohon gewang (Coryphaelata robx) (Hilakore et al., 2013). Tepung putak mengandung bahan organik $95,17 \%$, protein kasar 9,79\%, serat kasar $5,39 \%$, lemak kasar 0,84\%, dan BETN $79,15 \%$. Tepung putak dapat dimanfaatkan sebagai bahan sumber karbohidrat yang mudah dan murah diperoleh untuk digunakan dalam proses ensilase.

Isi rumen sapi merupakan salah satu limbah rumah potong hewan yang belum termanfaatkan, namun dapat digunakan sebagai sumber enzim pengganti enzim komersial dalam proses ensilase karena mengandung enzim selulase, xilanase, mananase, dan amylase (Budiansyah et al., 2010).

Penambahan aditif putak dan isi rumen bertujuan untuk mencukupi kebutuhan karbohidrat mudah larut, menstimulasi serta memaksimalkan kerja bakteri selama ensilase berlangsung. Kajian mengenai penambahan putak dan isi rumen sapi dalam proses pembuatan silase $C$. odorata belum dilakukan sehingga penelitian ini berupaya untuk mengkaji pengaruh level putak dan isi rumen terhadap kandungan tanin dan kandungan nutrisi silase $C$. odorata dalam waktu pemeraman yang berbeda.

\section{Materi dan Metode}

\section{Lokasi dan waktu penelitian}

Penelitian ini dilaksanakan dalam tiga tahapan, yaitu tahap persiapan, tahap pembuatan silase dan tahap analisis kimia. Tahap persiapan dan pembuatan silase dilaksanakan di Kupang-Nusa Tenggara Timur (NTT) dari bulan Maret-Mei 2015 di Laboratorium Mikrobiologi, Fakultas Peternakan Universitas Nusa Cendana. Analisis kimia dilaksanakan bulan JuniDesember 2015. Evaluasi tanin dan komposisi proksimat dilaksanakan di Laboratorium IImu dan Teknologi Pakan, Fakultas Peternakan, Institut Pertanian Bogor.

\section{Materi}

Bahan yang digunakan dalam penelitian ini meliputi tanaman C. odorata yang dipanen bulan Maret 2015 di padang penggembalaan yang ada di Nasipanaf, Desa Baumata Timur, Kecamatan Taebenu, Kabupaten Kupang, Nusa Tenggara Timur (NTT) dan tepung putak. Isi rumen sapi diperoleh dari rumah potong hewan Kotamadya Kupang, NTT. Isi rumen diperoleh dari rumen sapi bali yang diberi pakan jerami padi selama di rumah potong hewan. Alat yang digunakan meliputi silo dari botol plastik kapasitas 1 liter serta alat lainnya untuk analisis kandungan total tanin dan kandungan nutrien silase $C$. odorata.

\section{Metode}

Penelitian ini terdiri dari 3 tahap: tahap pertama persiapan bahan, tahap kedua pembuatan silase dan tahap ketiga analisis sampel.

Persiapan bahan. Pada tahap ini tepung putak disiapkan dengan cara batang pohon gewang (Coryphaelata robx) yang telah dipotong, diambil, dikeluarkan kulitnya, dicacah sekecil mungkin, dijemur di bawah sinar matahari hingga kering. Setelah kering, cacahan putak tersebut dibuat tepung.

Pembuatan silase. Setelah dipanen, daun tanaman $C$. odorata dipisahkan dari batangnya. Daun ini kemudian dicacah dan dilayukan dengan tujuan menurunkan kadar air sehingga siap untuk dibuat silase. Silase dibuat dengan mencampur daun $C$. odorata dengan bahan berupa putak $10 \%$ dari berat $C$. odorata dan isi rumen sapi segar masingmasing 5\% dan 10\%. Setelah dicampur, bahan tersebut dimasukan dalam wadah toples 1 liter, dipadatkan, ditutup rapat sehingga tidak ada udara yang masuk. Inkubasi dilakukan pada suhu ruang selama 21 hari. Sebagai pembanding, daun $C$. odorata dicampur dengan putak dan isi rumen segar seperti di atas tetapi tidak dilanjutkan proses fermentasi. Pemanenan silase 
dilakukan setelah 21 hari inkubasi. Setelah itu silase dikeringkan, digiling untuk analisis selanjutnya.

Penelitian pembuatan silase ini menggunakan 4 perlakuan penambahan aditif, yaitu CO (daun C. odorata), COP (daun C. odorata + tepung putak 10\%), COPR5 (daun C. odorata + tepung putak $10 \%+$ isi rumen sapi 5\%), dan COPR10 (daun C. odorata + tepung putak $10 \%$ + isi rumen sapi $10 \%$ ) dan lama pemeraman 0 hari dan 21 hari. Rancangan penelitian yang digunakan adalah Rancangan Acak Lengkap faktorial berkonfigurasi $4 \times 2$, dengan 4 kali ulangan. Faktor yang diamati yaitu faktor penambahan aditif (CO, COP, COPR5, COPR10) dan faktor fermentasi silase (0 hari, 21 hari).

Analisis sampel. Analisis sampel meliputi analisis total tanin dan kandungan nutrien silase $C$. odorata. Analisis total tanin menggunakan metode titrimetric (Atanassova dan Christova-Bagdassarian, 2009). Pengukuran nutrien bahan meliputi: kandungan bahan kering (BK), bahan organik (BO), protein kasar (PK), lemak kasar (LK), dan serat kasar (SK) silase $C$. odorata menggunakan metode AOAC (2005).

\section{Analisis data}

Data dianalisis menggunakan ANOVA (Analysis of Variance) untuk mengetahui pengaruh perlakuan terhadap peubah yang diamati, bila terdapat perbedaan pada peubah dilakukan uji lanjut Duncan $(P<0,05)$. Proses analisis data menggunakan SPSS versi 16.0.

\section{Hasil dan Pembahasan}

\section{Kandungan total tanin silase $\boldsymbol{C}$. odorata}

Kandungan total tanin silase $C$. odorata ditampilkan pada Tabel 1. Analisis varians menunjukkan bahwa penambahan aditif dan waktu fermentasi berpengaruh sangat nyata $(P<0,01)$ terhadap penurunan kandungan tanin silase $C$. odorata, namun tidak terdapat interaksi antar kedua faktor tersebut.

Penambahan aditif putak $10 \%$ dan isi rumen sapi $10 \%$ menurunkan total tanin $20,77 \%$, sedangkan penambahan putak $10 \%$ dan isi rumen sapi 5\% menurunkan total tanin $12,16 \%$. Peurunan total tanin oleh kedua perlakuan tersebut lebih disebabkan oleh level isi rumen. Sebab silase dengan hanya menambahkan putak 10\%, penurunan total tanin hanya 3,69\% saja. Enzim yang terdapat dalam isi rumen antara lain selulase dan amilase yang berkontribusi untuk memecah ikatan tanin-pati dan tanin-selulosa sehingga tanin terlepas sebagai tanin bebas. Tanin tidak hanya mengikat protein namun juga mengikat pati, selulosa, pektin serta alkaloid (Zucker, 1992). Putak dalam proses ensilase hanya berperan sebagai sumber makanan bagi mikroba sehingga tidak berkontribusi langsung terhadap penurunan tanin.

Waktu fermentasi 21 hari merupakan perlakuan yang tertinggi dalam menurunkan kandungan total tanin silase $C$. odorata bila dibanding dengan waktu fermentasi 0 hari. Hal ini dikarenakan selama proses ensilase, enzim selulase dan amilase dari isi rumen bekerja merusak ikatan tanin-enzim, taninprotein, tanin-pati serta tanin-selulosa, sedangkan 0 hari aktivitas enzim ini belum bekerja. Selain itu, kemungkinan enzim-enzim tersebut menghidrolisis lebih lanjut sebagian tanin, terutama yang larut menjadi senyawa lain selama proses fermentasi anaerobik berlangsung.

\section{Kandungan nutrien silase $\boldsymbol{C}$. odorata}

Komposisi nutrien C. odorata sebelum dan sesudah ensilase ditampilkan pada Tabel 2. Hasil analisis variansi menunjukkan bahwa perlakuan penambahan aditif berpengaruh sangat nyata $(P<0,01)$ terhadap kandungan BK silase $C$. odorata. Waktu fermentasi berpengaruh tidak signifikan terhadap kandungan BK serta tidak terdapat interaksi antara perlakuan penambahan aditif dan waktu fermentasi. Penurunan BK tertinggi terdapat pada perlakuan COP sebesar 9,98\%, diikuti perlakuan COPR10 dan COPR5 (10,37\%) dibanding kontrol $(12,26 \%)$. Penambahan tepung putak dalam pembuatan silase $C$. odorata menurunkan kandungan bahan kering. Hal ini dikarenakan aktivitas BAL dalam memfermentasi glukosa menjadi asam laktat selama ensilase sehingga terjadi kehilangan BK (McDonald et al., 1984).

Hasil analisis variansi menunjukkan bahwa penambahan aditif berpengaruh sangat nyata $(P<0,01)$ terhadap kandungan BO silase $C$. odorata. Waktu fermentasi berpengaruh nyata terhadap kandungan BO serta tidak terdapat interaksi antara perlakuan PA dan waktu fermentasi. Kandungan BO tertinggi terdapat pada perlakuan COPR10 yaitu sebesar 88,99\%, COPR5 (88,64\%), COP (88,52\%), dan kontrol (86,02\%). Penambahan putak dan isi rumen meningkatkan kandungan BO silase karena 
Tabel 1. Kandungan total tanin silase $C$. odorata (the content of total tannin from C. odorata silage)

\begin{tabular}{llccccc}
\hline \hline \multirow{2}{*}{$\begin{array}{l}\text { Peubah } \\
\text { (variables) }\end{array}$} & Hari (days) & \multicolumn{4}{c}{ Penambahan aditif (additive) } & \multirow{2}{*}{$\begin{array}{c}\text { Rerata } \\
\text { (average) }\end{array}$} \\
\cline { 3 - 6 } & & \multicolumn{1}{c}{ CO } & COP & COPR5 & COPR10 & \\
\hline \multirow{2}{*}{ Tannin (\%) } & 0 & $8,63 \pm 0,32$ & $8,11 \pm 0,14$ & $7,97 \pm 0,30$ & $7,46 \pm 0,09$ & $8,04 \pm 0,48^{\mathrm{a}}$ \\
$($ tannin (\%)) & 21 & $7,66 \pm 0,75$ & $7,57 \pm 0,76$ & $6,33 \pm 0,49$ & $6,03 \pm 0,41$ & $6,90 \pm 0,93^{\mathrm{b}}$ \\
& Rerata (average) & $8,14 \pm 0,75^{\mathrm{b}}$ & $7,84 \pm 0,58^{\mathrm{b}}$ & $7,15 \pm 0,95^{\mathrm{a}}$ & $6,74 \pm 0,81^{\mathrm{a}}$ & $7,47 \pm 0,93$ \\
\hline
\end{tabular}

$\mathrm{CO}=$ C. odorata; $\mathrm{COP}=$ C. odorata + putak $10 \%$ (C. odorata + putak meal 10\%); COPR5= C. odorata + putak $10 \%+$ isi rumen $5 \%$ (C. odorata + putak meal 10\% + rumen content 5\%); COPR10 $=$ C. odorata + putak $10 \%+$ isi rumen $10 \%$ (C. odorata + putak meal $10 \%+$ rumen content $10 \%)$.

a,b Superskrip yang berbeda pada kolom/baris yang sama menunjukkan berbeda nyata pada taraf uji $5 \%$ (uji selang berganda Duncan) (different superscripts at the same column / row show significantly different at the $5 \%$ test level (Duncan multiple test interval).

Tabel 2. Komposisi nutrien C. odorata sebelum dan sesudah ensilase (\%) (nutrient composition of C. odorata before and after ensilage (\%))

\begin{tabular}{|c|c|c|c|c|c|c|}
\hline \multirow{2}{*}{$\begin{array}{c}\text { Peubah } \\
\text { (variables) }\end{array}$} & \multirow{2}{*}{ Hari (days) } & \multicolumn{4}{|c|}{ Penambahan aditif (additive) } & \multirow{2}{*}{$\begin{array}{c}\text { Rerata } \\
\text { (average) }\end{array}$} \\
\hline & & $\mathrm{CO}$ & COP & COPR5 & COPR10 & \\
\hline \multirow{2}{*}{$\begin{array}{l}\text { Bahan kering } \\
\text { (dry matter) }\end{array}$} & 0 & $12,75 \pm 0,20$ & $10,10 \pm 0,16$ & $10,47 \pm 0,17$ & $10,50 \pm 0,20$ & $10,96 \pm 1,10$ \\
\hline & $\begin{array}{l}21 \\
\text { Rerata (average) }\end{array}$ & $\begin{array}{l}11,77 \pm 1,31 \\
12,26 \pm 1,01^{b}\end{array}$ & $\begin{array}{l}9,85 \pm 0,90 \\
9,98 \pm 0,61^{a}\end{array}$ & $\begin{array}{l}10,27 \pm 0,32 \\
10,37 \pm 0,26^{a}\end{array}$ & $\begin{array}{l}10,24 \pm 0,46 \\
10,37 \pm 0,36^{a}\end{array}$ & $\begin{array}{l}10,53 \pm 1,07 \\
10,74 \pm 1,09\end{array}$ \\
\hline \multirow{2}{*}{$\begin{array}{l}\text { Bahan organik } \\
\text { (organic } \\
\text { matter) }\end{array}$} & 0 & $86,12 \pm 0,12$ & $88,59 \pm 0,04$ & $88,66 \pm 0,03$ & $89,36 \pm 0,01$ & $88,18 \pm 1,27^{a}$ \\
\hline & $\begin{array}{l}21 \\
\text { Rerata (average) }\end{array}$ & $\begin{array}{l}85,93 \pm 0,69 \\
86,02 \pm 0,47^{a}\end{array}$ & $\begin{array}{l}88,45 \pm 0,36 \\
88,52 \pm 0,25^{b}\end{array}$ & $\begin{array}{l}88,63 \pm 0,08 \\
88,64 \pm 0,05^{b}\end{array}$ & $\begin{array}{l}88,61 \pm 0,10 \\
88,99 \pm 0,41^{c}\end{array}$ & $\begin{array}{l}87,90 \pm 1,23^{b} \\
88,04 \pm 1,24\end{array}$ \\
\hline \multirow{2}{*}{$\begin{array}{l}\text { Protein kasar } \\
\text { (crude protein) }\end{array}$} & 0 & $13,78 \pm 0,77^{a}$ & $14,40 \pm 1,69^{a b}$ & $15,45 \pm 1,03^{b c}$ & $21,61 \pm 1,24^{e}$ & $16,31 \pm 3,41$ \\
\hline & $\begin{array}{l}21 \\
\text { Rerata (average) }\end{array}$ & $\begin{array}{l}15,64 \pm 0,17 b^{c} \\
14,71 \pm 1,12\end{array}$ & $\begin{array}{l}16,04 \pm 0,35^{c} \\
15,22 \pm 1,43\end{array}$ & $\begin{array}{l}16,63 \pm 0,80^{c} \\
16,04 \pm 1,06\end{array}$ & $\begin{array}{l}20,10 \pm 0,93^{d} \\
20,86 \pm 1,30\end{array}$ & $\begin{array}{l}17,10 \pm 1,91 \\
16,71 \pm 2,75\end{array}$ \\
\hline \multirow{2}{*}{$\begin{array}{l}\text { Lemak kasar } \\
\text { (eter extract) }\end{array}$} & 0 & $7,73 \pm 0,29^{e}$ & $5,31 \pm 0,33^{d}$ & $5,04 \pm 0,65^{b c d}$ & $4,25 \pm 0,30^{a b}$ & $5,58 \pm 1,39$ \\
\hline & $\begin{array}{l}21 \\
\text { Rerata (average) }\end{array}$ & $\begin{array}{l}5,15 \pm 0,23^{c d} \\
6,44 \pm 1,40\end{array}$ & $\begin{array}{l}4,08 \pm 0,52^{a} \\
4,69 \pm 0,77\end{array}$ & $\begin{array}{l}4,03 \pm 0,95^{a} \\
4,53 \pm 0,93\end{array}$ & $\begin{array}{l}4,37 \pm 0,45^{a b c} \\
4,31 \pm 0,36\end{array}$ & $\begin{array}{l}4,41 \pm 0,71 \\
4,99 \pm 1,24\end{array}$ \\
\hline \multirow{3}{*}{$\begin{array}{l}\text { Serat kasar } \\
\text { (crude fiber) }\end{array}$} & 0 & $13,43 \pm 0,88^{c}$ & $13,33 \pm 0,15^{c}$ & $13,31 \pm 0,17^{c}$ & $14,28 \pm 0,43^{d}$ & $13,59 \pm 0,61$ \\
\hline & 21 & $9,95 \pm 0,32^{b}$ & $8,98 \pm 0,47^{a}$ & $8,44 \pm 0,73^{a}$ & $8,30 \pm 0,38^{a}$ & $8,92 \pm 0,80$ \\
\hline & Rerata (average) & $11,69 \pm 1,96$ & $11,16 \pm 2,35$ & $10,88 \pm 2,65$ & $11,30 \pm 3,22$ & $11,25 \pm 2,48$ \\
\hline
\end{tabular}

adanya sumbangan BO dari putak dan isi rumen. Waktu fermentasi 21 hari berpengaruh menurunkan kandungan BO silase. Hal ini dikarenakan selama proses fementasi berlangsung terjadi penguraian bahan organik oleh bakteri untuk kelangsungan hidupnya. Walaupun terdapat penambahan sumber karbohidrat, namun diduga jumlah yang diberikan belum mencukupi kebutuhan bakteri selama ensilase sehingga terjadi penurunan kandungan BO silase.

Kandungan PK silase C. odorata ditampilkan pada Tabel 2. Hasil analisis variansi menunjukkan bahwa penambahan aditif berpengaruh sangat nyata $(P<0,01)$ terhadap kandungan PK silase $C$. odorata. Waktu fermentasi berpengaruh nyata terhadap kandungan PK serta terdapat interaksi yang nyata antara perlakuan PA dan waktu fermentasi. Peningkatan PK terjadi pada perlakuan COPR10 sebelum ensilase karena adanya penambahan PK dari putak dan isi rumen. Namun, setelah fermentasi terjadi penurunan yang dikarenakan adanya penurunan kandungan $\mathrm{N}$ selama proses ensilase akibat meningkatnya proporsi senyawa $\mathrm{N}$ yang larut dalam effluent (Ginting et al., 2011). Interaksi terbaik antara penambahan aditif dan waktu fermentasi terdapat pada perlakuan COPR10 0 hari. Hal ini diduga sebagai akibat adanya penambahan rumen dan isi rumen serta belum terurainya kandungan $\mathrm{N}$ akibat proses fermentasi. 
Penambahan aditif dan waktu fermentasi sangat nyata $(P<0,01)$ menurunkan kandungan LK serta terdapat interaksi antara penambahan aditif dan waktu fermentasi. Perlakuan dengan kandungan LK terendah terdapat pada perlakuan COPR5 21 hari. Hal ini diduga karena kandungan LK putak dan isi rumen rendah serta telah terpecahnya ikatan kompleks trigliserida menjadi ikatan yang lebih sederhana antara lain dalam bentuk asam lemak dan alkohol.

Analisis varians untuk kandungan SK silase C. odorata (Tabel 2) menunjukkan bahwa penambahan aditif secara nyata mempengaruhi SK silase, waktu fermentasi sangat nyata $(P<0,01)$ mempengaruhi SK serta terdapat interaksi antara penambahan aditif dan waktu fermentasi. Perlakuan COPR10 21 hari merupakan perlakuan dengan kandungan SK terendah. Hasil penelitian ini senada dengan yang dilaporkan oleh Hidayat (2009) bahwa fermentasi dapat menurunkan kandungan serat kasar kulit singkong dari $21,2 \%$ menjadi $14,96 \%$. Penurunan kandungan serat kasar silase $C$. odorata dikarenakan enzim selulase dari isi rumen memecah serat $C$. odorata menjadi molekul karbohidrat yang lebih sederhana.

\section{Kesimpulan}

Silase $C$. odorata dengan penambahan putak $10 \%$ dan isi rumen sapi hingga level $10 \%$ mampu menurunkan total tanin serta mampu mempertahankan kualitas nutrisi silase $C$. odorata bila dibandingkan dengan silase tanpa aditif putak dan isi rumen.

\section{Daftar Pustaka}

Akinmoladun, A. C., E. M. Obuotor and E. O. Farombi. 2010. Evaluation of antioxidant and free radical scavenging capacities of some Nigerian indigenous medicinal plants. J. Med. Food 13: 444451.

Atanassova, M. and V. ChristovaBagdassarian. 2009. Short Communication: Determination of tannins content by titrimetric method for comparison of different plant species. J. University Chem. Tech. Metallurgy. 44: 413-415.
AOAC. 2005. Official Methods of Analysis. $17^{\text {th }}$ edn. Assoc of Official Analytical Chemist, Washington DC.

Budiansyah, A., Resmi, K. G. Wiryawan, M. T. Soehartono, Y. Widyastuti, dan N. Ramli. 2010. Isolasi dan karakterisasi enzim karbohidrase cairan rumen sapi asal Rumah Potong Hewan. Media Peternakan 33: 36-43.

Ginting, S. P., A. Tarigan, dan R. Krisnan. 2011. Konsumsi fermentasi rumen dan metabolit darah kambing sedang tumbuh yang diberi silase $I$. arrecta dalam pakan komplit. Jurnal IImu Ternak dan Veteriner 17: 49-58.

Hai, P. V., H. Everts, D. V. Tien, J. T. Schonewille and W. H. Hendriks. 2012. Feeding Chromonaela odorata during pregnancy to goat dams affects acceptance of this feedstuff by their offspring. Appl. Anim. Behav. Sci. 137: 30-35.

Hawaii Department of Agriculture. 2016. Chromolaena odorata. http://manoa.hawaii.edu/hpicesu/DPW/ chrodo_flier.pdf. Diakses pada 15 Maret 2016.

Hidayat, C. 2009. Peluang penggunaan kulit singkong sebagai pakan unggas. Seminar Nasional Teknologi Peternakan dan Veteriner, 13-14 Agustus 2009, Bogor, pp. 655-665.

Hilakore, M. A., Suryahadi, K. Wiryawan, dan D. Mangunwijaya. 2013. Peningkatan kadar protein putak melalui fermentasi oleh kapang Trichoderma reesei. Jurnal Veteriner 14: 250-254.

McDonald, P., R. A. Edwards and J. F. D. Greenhalgh. 1984. Animal Nutrition. $4^{\text {th }}$ edn. English Language Book Society. Longman, London.

Mulik, Y. M., M. Ridla, I. Prihantoro and M. L. Mullik. 2016. Anaerobic fermentation effectively reduces concentration of total tannins in Siam Weed (Chromolaenan odorata). Jurnal IImu Ternak dan Veteriner 21: 19-21.

Zucker, W. V. 1992. Tannins does structure determination an ecological perspective. Amer. Naturalist 121: 335365. 